\title{
Stereotypes and valuations of Peruvian social groups in a sample of wealthy people from Lima
}

\section{Estereotipos y valoración de grupos sociales peruanos en una muestra de personas de sectores sociales privilegiados de Lima}

\author{
Gina Pamela Pancorbo Valdiviaa, Mathias Schmitz ${ }^{\mathrm{b}, \mathrm{c},}$, Ian Nightingale Ferrer ${ }^{\mathrm{c}}$, \\ Andrés Manuel Palacios Agurto ${ }^{c}$, Agustín Espinosa ${ }^{c}$ \\ ${ }^{a}$ Ghent University, Belgium \\ bUniversité Catholique de Louvain, Belgium \\ 'Pontificia Universidad Católica del Perú, Perú
}

\begin{abstract}
Background: Peruvian society is characterized by its ethnical, cultural and socioeconomic diversity, which leads to complex intergroup relations. Objective: To contribute to understanding this phenomenon, the present study aims to examine the stereotypical representations and prejudice towards different Peruvian social groups by high-socioeconomic-status group members from Lima. Method: The research used a mixed-method design for complementing two different approaches: a quantitative one, where questionnaires were administered to a sample of 90 participants; and a qualitative one, in which semi-structured interviews were conducted with 10 participants. Results: The results showed that the participants identified high- and low-status groups in the Peruvian society, and hold ambivalent stereotypical representations towards them. The participants identified and valued White Peruvians as high-status group members, who are competent and developed but also corrupt. On the other hand, they identified and valued Amazonian and African Peruvians to a lesser extent, who are considered as low-status, undeveloped but joyful groups. Conclusion: The study emphasizes the importance of social class attributes used in the formation of stereotypical representations and prejudice towards different Peruvian social groups.
\end{abstract}

Keywords: stereotypes, prejudice, intergroup relation, mixedmethod design.

Para citar este artículo:

Pancorbo, G. P., Schmitz, M., Nightingale, I., Palacios, A. M., \& Espinosa, A. (2019). Stereotypes and valuations of Peruvian social groups in a sample of wealthy people from Lima. Liberabit, 25(2), 159178. https://doi.org/10.24265/liberabit. 2019.v25n2.03

\section{Resumen}

Antecedentes: La sociedad peruana se caracteriza por su diversidad étnica, cultural y socio-económica, lo cual lleva al establecimiento de complejas relaciones intergrupales. Objetivo: Para contribuir a la comprensión de este fenómeno, el presente estudio tiene como objetivo examinar las representaciones estereotípicas y el prejuicio hacia diferentes grupos sociales de la sociedad peruana, expresados por personas de sectores socio-económicos altos de la ciudad de Lima. Método: La investigación comprende un diseño mixto que complementa dos diferentes aproximaciones: una cuantitativa, donde cuestionarios fueron aplicados a una muestra de 90 participantes; y una cualitativa, en donde una entrevista semiestructurada fue aplicada a 10 participantes. Resultados: Los resultados muestran que los participantes identifican grupos de alto y bajo estatus en la sociedad peruana y mantienen representaciones estereotípicas ambivalentes hacia estos. Los participantes identifican y valoran a los peruanos blancos como un grupo de clase alta, competente y desarrollado, pero también corrupto. Mientras tanto, se identifican y valoran menos a los peruanos amazónicos y afroperuanos, los cuales son considerados como grupos de bajo estatus, subdesarrollados pero alegres. Conclusión: El estudio enfatiza en la importancia asignada a los atributos de clase social que se utilizan para la construcción de representaciones estereotípicas y prejuicio hacia diversos grupos sociales en el Perú.

Palabras clave: estereotipos, prejuicio, relaciones intergrupales, diseños mixtos.

Este es un artículo Open Access bajo la licencia Creative Commons Atribución-NoComercial-CompartirIgual 4.0

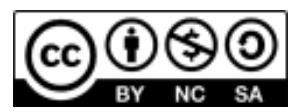

Universidad de San Martín de Porres, Lima - Perú 


\section{Introduction}

The present research aims to analyze the stereotypical representation and valuation of socioethnic groups that make up the Peruvian society from the point of view of high-socioeconomic-status groups. In this regard, the study nicely complements previous research that have assessed these representations from low and middle socioeconomic status samples (Espinosa, Calderón-Prada, Burga, \& Güímac, 2007; Genna \& Espinosa, 2012; Pancorbo, Espinosa, \& Cueto, 2011).

Social categorization is a cognitive process that allows separating, classifying and organizing the environment into social categories (Tajfel \& Turner, 1986) according to the belief that members of these categories share common traits (Fiske, 1998). Therefore, the process allows organizing the social medium into comprehensible units of information (Abrams \& Hogg, 1990), and guides the attitudes, actions and behavior intentions of an individual towards others (Tajfel \& Forgas, 1981). This process has repercussions for the formation and valuation of collective identities, because it creates and defines the place of an individual, or group of individuals, in society. This occurs since categorization implies a separation: the idea of them (out-group) versus the idea of us (in-group) (Tajfel \& Turner, 1986).

In this context, an individual will tend to positively represent his/her in-group and to differentiate it from out-groups, while occasionally attributing negative traits to them (Tajfel \& Turner, 1979; Turner, Brown, \& Tajfel, 1979). The occasional tendency to devaluate the out-group helps strengthen the group self-esteem and increase the in-group status. This tendency is also congruent with the attribution of stereotypes and prejudice (Fein \& Spencer, 1997), and has led to the assumption that stereotypes and prejudice are inevitable consequences of social categorization (Allport, 1954; Hamilton, 1981; Tajfel, 1969).

Stangor (2009) defines stereotypes as knowledge structures formed by features and attributes observed as typical of social groups or members to those groups. They are shared socially (Schaller \& Crandall, 2004) and tend to be stable in time, although they can vary according to different elements and conditions of the social context, such as the information available in the environment and the motivation to process this information (Bodenhausen, Mussweiler, Gabriel, \& Moreno, 2001). Prejudice, on the other hand, is defined as a negative attitude towards a group or person due to their belonging to a certain social category (Allport, 1954).

Stereotyping and prejudicing are psychological processes that become evident through discriminatory behavior legitimated by social, political and cultural structures that tend to reinforce power hierarchies and inequities (Jost \& Banaji, 1994; Stangor, 2009; e.g., Volpato, Andrighetto, \& Baldissarri, 2017). Both stereotypes and prejudice are founded on three main characteristics: age, gender and race (Fiske, 2000). However, they can also be based on less salient attributes such as social class, nationality, linguistic group and sexual preference, among others (HydeClarke, 2008).

Although it is well known that racism exists in many countries, a frequent problem found by researchers is the fact that people hide their expressions of prejudice (Zárate, 2009). In this sense, Gaertner and Dovidio (1986; see also Dovidio, Pearson, \& Penner, 2018) introduced the concept of aversive racism, which refers to the modern expression of prejudice in which people are not aware of the attitudes and stereotypes they possess. Under these circumstances, prejudice does not necessarily translate into open antipathy or rejection towards an out-group or its members. Instead, apparently positive or benevolent characteristics are attributed to this outgroup, characteristics which contribute to strengthen the group's subordinated position on society.

Regarding the content of stereotypes, independent lines of research from different countries show two fundamental dimensions, warmth and competence, and 
underlie both personal and social judgments (Durante, Tablante, \& Fiske, 2017; Fiske, 2015; Fiske, Cuddy, Glick, \& Xu, 2002). From an evolutionary perspective, these dimensions would stem from basic survival needs, that is, to distinguish potential allies from enemies, and to compete for status and resources (Van der Toorn et al., 2015). Therefore, warmth and competence would respectively derive from the group's perceived intentions and their capacity to carry them out. For instance, the stereotype content model (SCM; Fiske et al., 2002) suggests that, on the one hand, perception of low competiveness predicts warmth, which is associated to traits such as honesty, kindness, helpfulness and trustworthiness; and, on the other hand, perceived (lack of) status would predict competence, which is related to traits such as skill, intelligence and efficiency.

On this regard, it has been argued that the tendency to ascribe competence to high-status targets would serve as a hierarchy-legitimizing function (Van der Toorn et al., 2015). This idea would be rooted in the merit principle, which supports that distribution of outcomes such as jobs, wealth or power should be based exclusively on an individual's merit (i.e., competence, ability or talent). Therefore, other inputs such as ethnicity or gender should not be taken into account when distributing outcomes. However, in practice, this principle operates in such a manner to justify and reinforce the status quo (Song Hing, Bodocel, Zanna, Garcia, Gee, \& Orazietti, 2011).

The levels of association between competence and warmth constitute four types of stereotypes and intergroup relations. The envious stereotype stems from the perception of high competence but low warmth (i.e., Asians, rich people, Jews) and elicits emotions of envy, whereas the paternalistic stereotype is associated with groups viewed as incompetent but warmth (disabled people, older people) and generates emotions of pity. On the other hand, groups regarded as high on both competence and warmth (i.e., heterosexuals, in-group, allies) will rise emotions of admiration, whereas feelings of disgust and contempt will arouse by groups perceived as incompetent and cold (poor people, drug addicts). Moreover, it has been suggested that warmth stereotypes will attenuate active harm (harassing) and elicit active facilitation (helping) towards the target, whereas competence stereotypes will attenuate passive harm (neglecting) and elicit passive facilitation (associating) (Cuddy, Fiske, \& Glick, 2007).

Although these two dimensions produce four quadrants, research has focused on the so-called mixed stereotypes (i.e., rich, disabled, women) as well as on the fact that social judgments tend to operate according to a compensation pattern such that targets higher on one of the two dimensions tend to be seen as low on the other dimension (Yzerbyt, Provost, \& Corneille, 2005; for a review, see Kervyn, Yzerbyt, \& Judd, 2010; Yzerbyt, 2016, 2018). Conditions under which the compensation effect emerges are still largely unclear. Cambon, Yzerbyt and Yakimova (2015) pointed out that asymmetry (perceived as stable and legitimate) combined with low levels of intergroup conflict may be necessary conditions to give rise to this pattern. Moreover, the compensatory pattern also seems to be moderated by group membership. Specifically, in the context of social comparison, both high- and low- status group members tend to exhibit in-group bias in their in-group-favored dimension, while out-group favoritism in the other dimension. In particular, high-status group members would manifest an in-group bias in the status-relevant dimension (i.e., competence) and out-group bias in the statusirrelevant dimension (i.e., warmth). The opposite effect has been observed for members of the lowstatus group. These compensatory patterns called 'noblesse oblige effect' for the high-status group, and 'social creativity' for the low status one, are prone to take place when non-discriminant pressure are at stakes, and would serve as a way to enhance and protect the social identity of group members (Cambon et al., 2015; Cambon \& Yzerbyt, 2018; Yzerbyt \& Cambon, 2017). 
In the Peruvian context, stereotypes and prejudice are of common use and help to establish boundaries among different social groups. In this regard, different public-opinion studies show that Peruvians recognize discrimination as very common in their context and share the subjective feeling of often being discriminated (Instituto de Opinión Pública [Institute for Public Opinion] - Pontificia Universidad Católica del Perú [Pontifical Catholic University of Peru], IOPPUCP, 2018; Latinobarómetro, 2011). Ethnic-racial categories are not the only discriminatory axis in Peru: prejudice in the country tend to be based on ethnicity and social class (IOP-PUCP, 2018; León, 1998). Thus, a complex relationship between ethnicity, race, social class and economic conditions is established as the basis of discrimination (Espinosa \& Cueto, 2014; Reding, 2007). An example of this is the association of Indigenous people with poverty in rural areas of the country (Avilés, 2016; Portocarrero, 1992).

Several studies with samples from the low and middle socioeconomic status have shown that participants of these surveys distinctively recognize the presence of high- and low-status groups in the Peruvian society. White Peruvians are clearly part of high-status groups, while Peruvians of Andean and Amazonian descent, as well as African Peruvians, belong to low-status groups (Espinosa, 2011; Espinosa et al., 2007; Genna \& Espinosa, 2012; Pancorbo et al., 2011). In terms of identification, it is not surprising that most Peruvians tend to identify with the Mestizo group and the middle-class-status groups, since both conditions imply distancing themselves from the nation's indigenous component and the low-status groups (Espinosa, 2011; Portocarrero, 2006).

More specifically, studies show that White Peruvians are associated to positive stereotypes such as development, capacity, success and efficacy (Espinosa; 2011; Espinosa et al., 2007; Genna \& Espinosa, 2012; Pancorbo et al., 2011). This, according to Fiske et al. (2002), corresponds to a stereotypical representation of high competence. However, the representation of White Peruvians is ambivalent, since this group is also related to negative traits associated with low warmth such as individualism, lack of patriotism and corruption (Espinosa; 2011; Espinosa et al., 2007; Genna \& Espinosa, 2012; Pancorbo et al., 2011).

On the other hand, Andeans, Amazonians and African Peruvians are characterized as being conformist, backward, underdeveloped and incapable, all of which are associated with a low-competence profile (Cueto, 2017; Espinosa, 2011; Espinosa et al., 2007; Genna \& Espinosa, 2012; Pancorbo et al., 2011). However, these groups are also seen as brave, patriotic and supportive, which brings them closer to high warmth and affective representation (Cueto, 2017; Espinosa; 2011; Espinosa et al., 2007; Genna \& Espinosa, 2012; Pancorbo et al., 2011).

Peruvians of Asian descent are related to positive characteristics such as hard work, honesty, success and capacity. Members of the middle socioeconomic class have the most positive representation of this group (Espinosa, 2011; Espinosa et al., 2007; Genna \& Espinosa, 2012). However, samples of scarce economic resources have a rather vague representation of this group and tend to associate them with low warmth attributes (Pancorbo et al., 2011).

In the abovementioned studies, the categories «Peruvians in general» and «Mestizos» are characterized in a similar manner. Both groups were perceived as hard working, joyful, unreliable, liars and untrustworthy. In general, they share characteristics with the other assessed categories, being thus placed in an intermediate point between high- and low-status groups.

Overall, despite stereotypical representations being consistent throughout the aforementioned studies, certain differences can be observed according to the social and economic characteristics of the samples. In studies with middle-class samples, most participants identified themselves with the Mestizo and White categories (Espinosa, 2011; Espinosa et al., 2007; 
Genna \& Espinosa, 2012). On the other hand, a study with low-economic-class samples showed that most participants identified themselves with the Andean, Mestizo and Amazonian groups (Pancorbo et al., 2011).

Middle-social-class samples not only identified themselves more with White Peruvians but also valued them more positively (Espinosa, 2011; Espinosa et al., 2007; Genna \& Espinosa, 2012). On the contrary, according to Pancorbo et al. (2011), the participants reported a better valuation of low-status groups (Andean and Amazonian Peruvians) since they felt more identified with these categories (Pancorbo et al., 2011).

The present research complements previous studies that used low- and middle-socioeconomicstatus samples (Espinosa et al., 2007; Genna \& Espinosa, 2012; Pancorbo et al., 2011), and studied stereotypical representations and prejudice from the perspective of high-socioeconomic-status group members. The assessed social groups were the following: Mestizos ${ }^{1}$, Andeans, Amazonians, Asians, African Peruvians and White Peruvians. In addition, the stereotypes and prejudice towards the broad category of Peruvians in general were also analyzed. In this sense, the first part of the present study is based on a quantitative method, and seeks to describe the attributes associated with each social group and their respective valuation, positing that the least valued groups are the ones against whom the participants hold the strongest prejudice. In addition, the perceived valuation of each group was also assessed in order to examine which are the groups that are the most and the least valued in the Peruvian society from the participants' points of view. The second part of this research is built on a qualitative analysis of interviews, and aims to complement and provide further insights on the stereotypical representation and valuation of the different Peruvian social groups.

\section{Method}

\section{Participants}

In the quantitative part of the study, a convenience sample of 90 people from Lima, Peru (42.2\% female), whose ages ranged between 18 and $58(M=30.5$, $S D=11.7$ ), participated in the study. From those, $70 \%$ were on the range of 18 to 30 years old. The participants were screened using the snowball technique in geographical regions of Lima that concentrated the highest proportion of people that belonged to high or middle-high socioeconomic levels (e.g., Miraflores, Surco, La Molina, etc.; APEIM, 2010, 2018). It is noteworthy to mention that only around $5 \%$ of the inhabitants of Lima have a high socioeconomic status (APEIM 2010, 2018). The criteria of the Peruvian Association of Enterprises and Market Research (APEIM, 2010) were used to categorize the participants' socioeconomic level. Most participants belonged to the high socioeconomic level (A1, A2; 92.2\%) and the rest belonged to the middlehigh socioeconomic level (B1; 7.8\%), were attending college (54.7\%) or completed college studies (31.7\%), lived in areas of Lima characterized by high concentrations of people of the same high socioeconomic level (> 40\%, APEIM, 2010), and were single (67.8\%) or married (23.3\%).

Regarding the qualitative part, a convenience sample of 10 people ( 7 males and 3 females) of the high socioeconomic level whose ages ranged between 18 and 30 participated in the study. The sample size followed the saturation principle of saturation of categories, and capacity of collection of data and analysis (Hernandez, Fernandez, \& Baptista, 2010). The participants' screening was conducted by the snowball technique, taking into account that these subjects should share similar characteristics to the participants of the first part of the study.

The Royal Spanish Academy (RAE) defines Mestizo as a person born to a father and mother of different races, especially to a White man and an American Indigenous woman, or an American Indigenous man and a White woman. 


\section{Measures}

\section{Control data questionnaire}

The sheet requested information on the following demographic data: age, sex, birthdate and socioeconomic level. The socioeconomic level (APEIM, 2010) was assessed through the inspection of the following indicators: level of instruction of the person responsible for the family, functioning appliances at home (computer, washing machine, telephone, etc.), number of people living in the house, number of rooms that are used exclusively to sleep, and predominant material of the house floors.

\section{Social stereotypes scale (Espinosa, 2003)}

It measures stereotypes associated to social groups using a list of 24 adjectives obtained by Espinosa (2003) in a study on national identity. Previous studies have shown that the scale has adequate evidence of construct validity. The adjectives were obtained from a qualitative survey, in which the participants openly described each of the seven groups: Mestizos, Andean Peruvians, Amazonian Peruvians, Asian Peruvians, African Peruvians and White Peruvians. These groups characterize ethnical and geographical group origins according to social specialists (Espinosa, 2003) and have been used as social categories in several studies to evaluate stereotyping processes in the Peruvian context (Pancorbo et al., 2011; Espinosa, et al., 2007). In addition, the category of «Peruvians in general» was used to characterize the national identity of the participants. The results of previous studies provided the necessary evidence of construct validity to use the social stereotypes scale in the present study.

The adjectives were presented to the participants who were asked to indicate which group, according to the opinion of the majority, is characterized by each one of those attributes. Two possible answers are presented: one (1) if the adjective was characteristic of the group or zero (0) if the adjective was not characteristic of the group. The 24 adjectives included positive, negative or neutral attributes, as well as three adjectives that specifically corresponded to the social class categorization of the groups (low class, middle class and high class).

\section{Social identification measures (Espinosa et al., 2007)}

The social identification scale was elaborated and validated by Espinosa et al. (2007). The seven questions measure the degree of identification with different social groups through the following statement: «Considering the groups of Peruvians previously mentioned, which is your degree of identification with Peruvians in general/Mestizos/ Andeans/Amazonians/Asians/African Peruvians/ Whites?» Each question has a 1 to 5 scale, where 1 $=$ «None» and $5=$ «Totally». In the present study, the internal consistency of the scale was .67.

\section{Social groups valuation measures (Espinosa et al., 2007)}

The social identification scale was elaborated and validated by Espinosa et al. (2007). The first part of the instrument contains seven indicators that measure the participants' own valuation for each of the seven social groups. The indicators were introduced after the general question «Which is your valuation of the following groups?» Each indicator has a response scale of 0 to 10 , where $0=$ «Very poor» and $10=$ «Very good». The internal consistency of this part of the scale was .85 .

The second part of the instrument contained other seven indicators that measured the perceived valuation of each of the social groups. The indicators followed the question «How do you think other Peruvians value the following groups?» As in the first part, the scale of responses ranged from 0 to 10 , where $0=$ «Very poor» and $10=$ «Very good». The internal consistency of this part of the scale was .78. 


\section{Semi-structured interview guide}

The instrument aimed to explore stereotypical representations and prejudice regarding the social groups, and the rationality behind the attributes associated with each group of the first part of the study. Therefore, the guide was developed based on the quantitative results of Study 1. It included the five adjectives most related with each of the seven groups (Mestizos, Andean Peruvians, Amazonian Peruvians, Asian Peruvians, African Peruvians, White Peruvians and Peruvians in general) in order to know if the participants agreed with the description, the reasons why they agreed or not, and if they could add other attributes, considering what they have experienced with members of the certain group. In addition, the participants' representations of the relationship between Peruvian social groups were also explored in the interviews.

\section{Procedure}

\section{Data collection and analysis}

Due to its complexity, the stereotype and prejudice assessment was performed following a mixed design method at a primary level (Heyvaert, Maes, \& Onghena, 2011). According to Heyvaert, et al. (2011), this type of method aims at collecting qualitative and quantitative data using a diverse form of techniques such as questionnaires and interviews. The method seeks to converge the quantitative and qualitative approach in a way that, for example, the first method can contribute to expand the findings of the second one in a sequential strategy (Creswell, 2003). This type of sequential strategy was used in the present research with the objective that the qualitative results of the second part of the study can expand and exemplify the quantitative results. A similar mixed-method design was used in a study by Pancorbo et al. (2011) that aimed to explore the stereotypes and prejudice of a sample of low socioeconomic class members of the Peruvian society.
In the first part of the study, once the participants accepted to take part in the study, they were asked to read carefully an informed consent document which contained information regarding the purposes of the study; ethical considerations regarding the anonymity of the data collection, treatment and report; as well as contact information for any further question. Once they signed the informed consent document, the questionnaires were administrated individually.

An exploratory analysis of the data was performed in order to check the presence of missing cases, outliers, and verify normality assumptions. In order to know which attributes were part of the stereotypical representations of the participants, descriptive and correspondence analyses were performed. This last analysis allowed to display stereotype responses of the participants around social groups in a two-dimensional graphical form.

In addition, to assess which are the social groups that the participants hold the greatest social identification, as well as the highest valuation and perceived valuation, due to lack of normality, Friedman's ANOVA was conducted and effect sizes $(r)$ were obtained in each case. The category «Peruvians in general» was not considered in the group comparison, as the objective was to differentiate the identification and valuation of the participants towards specific group categories that are part of the Peruvian society. The relationship between the social identification and valuation of each social group by the participants was analyzed using Spearman rank correlation. Finally, to understand the differences between the explicit and implicit measures of prejudice of the participants, a paired sample t-test with bootstrapping (1000 iterations) was performed. All data was analyzed using the IBM SPSS ${ }^{\circledR}$ Statistics version 21.

In the second part of the study, each participant was contacted separately to set up an interview. They took place in the participants' house or place of work in appropriate rooms with no distractions. An informed 
consent document was read to each participant explaining the objectives and the ethical considerations of the study. The participant signed the document upon agreeing to participate. Each interview had a duration of approximately 40 minutes and was recorded in audio. Afterwards, interviews were transcribed and reviewed with the aim of establishing categories for the topics of interest. Once the categories were identified and established, all the information was codified using the Atlas Ti software (version 5). Following this codification, the material obtained was interpreted and reported.

\section{Results}

\section{Part one: quantitative results}

The exploratory analyses showed that the identification and valuation items were not normally distributed. Data inspection indicated the absence of missing cases and a small number of outliers, which were not eliminated.
The five attributes showing the highest incidence in the description of the evaluated social groups were identified. Table 1 shows the frequency with which each attribute was assigned to the abovementioned groups, showing the core elements in their stereotypical representations.

As can be seen, the attribute «hardworking» and others related to the different socioeconomic classes are most commonly used in the description of the social groups. This suggests the interdependence between ethnic and socioeconomic attributes in the perception of Peruvian groups. Regarding the previous statement, high-status groups (Whites, Asians and Mestizos) are related to the middle and high class, while low-status groups (Andeans, Amazonians and African Peruvians) are mainly associated with the low class.

A correspondence analysis $\left(X^{2}=1339.77, p<\right.$ $.001)$ explained the $36.70 \%$ of the inertia, and showed the relationship between the evaluated social categories and the 27 stereotypical attributes.

\section{Table 1}

Main attributes associated with the evaluated social categories

\begin{tabular}{|c|c|c|c|c|c|c|}
\hline PG & MP & WP & AS & AP & Amp & A-P \\
\hline Hardworking & Hardworking & High class & Hardworking & Hardworking & Joyful & Joyful \\
\hline $66.7 \%$ & $67.8 \%$ & $67.8 \%$ & $91.1 \%$ & $78.9 \%$ & $74.4 \%$ & $81.1 \%$ \\
\hline JoyfulMiddle class & Individualist & Middle class & Low class & Low class & Hardworking & \\
\hline $63.3 \%$ & $57.8 \%$ & $61.1 \%$ & $64.4 \%$ & $63.3 \%$ & $56.7 \%$ & $71.1 \%$ \\
\hline Conformist & Conformist & Successful & Competent & Supportive & Backward & Low class \\
\hline $57.8 \%$ & $46.7 \%$ & $55.6 \%$ & $55.6 \%$ & $45.6 \%$ & $41.1 \%$ & $64.4 \%$ \\
\hline Competent & Competent & Competent & Trustworthy & Backward & Hardworking & Supportive \\
\hline $44.4 \%$ & $36.7 \%$ & $47.8 \%$ & $52.2 \%$ & $41.1 \%$ & $37.8 \%$ & $34.4 \%$ \\
\hline Supportive & Joyful & Developed & Developed & Conformist & Supportive & Middle class \\
\hline $40.0 \%$ & $34.4 \%$ & $47.8 \%$ & $43.3 \%$ & $35.6 \%$ & $35.6 \%$ & $33.3 \%$ \\
\hline
\end{tabular}

Note: $\mathrm{PG}=$ Peruvians in general; $\mathrm{MP}=$ Mestizo Peruvians, $\mathrm{WP}=$ White Peruvians, $\mathrm{AS}=$ Asian Peruvians, $\mathrm{AP}=\mathrm{Andean}$ Peruvians, Amp = Amazonian Peruvians, A-P = African Peruvians. 
Figure 1 shows that Andean Peruvians share some characteristics with Amazonian Peruvians and African Peruvians whose attributes are: being incompetent, backward, unsuccessful, supportive, brave and from low class. Closely in the map, Mestizos and Peruvians in general have negative attributes such as being liars, conformists, lazy and unreliable. Far away from these groups, White Peruvians are described as being from high class, individualist, successful and corrupt, and Asian Peruvians are perceived as reliable, honest, trustworthy and developed. These last two groups are located at a great distance from other Peruvian groups and from one to the other, which evidences their distinctiveness.

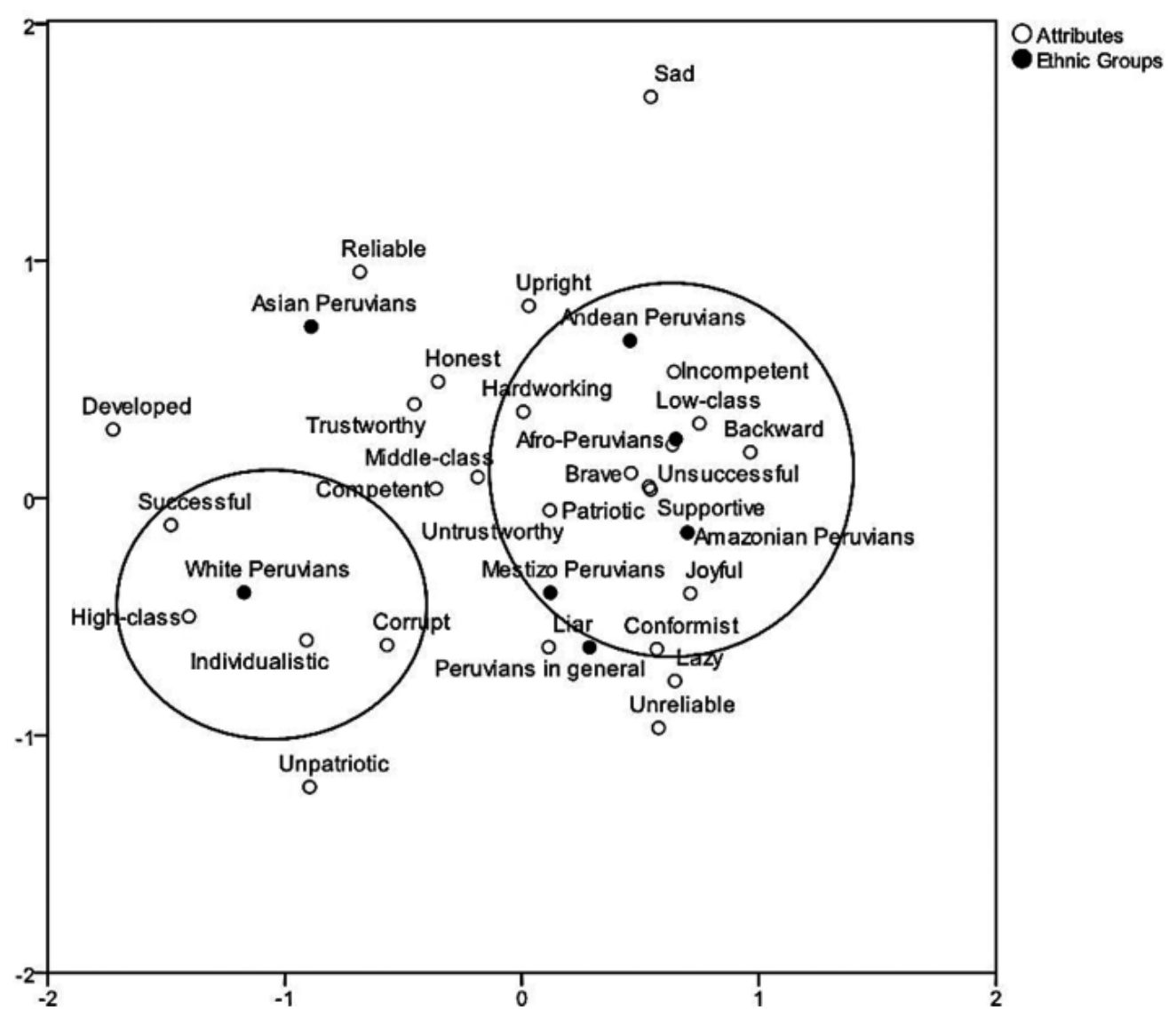

Figure 1. Correspondence analysis of stereotypical characteristics by social groups.

Table 2 presents means and standard deviations of participants' group identification and valuation. The results indicated that there are statistically significant differences in the identification of the participants towards social groups $\left(\chi^{2}(5)=195.54, p<.001\right)$, without considering their identification with Peruvians in general. The social identification of the participants with White Peruvians was higher than with Asian Peruvians $(p<.001, r=.94)$, Amazonians $(p<.001$, $r=.86)$, African Peruvians $(p<.001, r=.81)$ and Andeans $(p<.001, r=.63)$. In addition, the participants identified with Mestizos significantly more than with Asian Peruvians $(p<.001, r=.77)$, Amazonians $(p<.001, r=.69)$, African Peruvians $(p<.001, r=.64)$ and Andean Peruvians $(p<.001$, $r=.45)$. 
Table 2

Means and standard deviations of social identification and valuation towards social groups

\begin{tabular}{lcclc}
\hline \multirow{2}{*}{\multicolumn{1}{c}{ Group }} & \multicolumn{2}{c}{ Identification } & \multicolumn{2}{c}{ Valuation } \\
\cline { 2 - 5 } & $M$ & $S D$ & $M$ & $S D$ \\
\hline Peruvians in general & 3.42 & 0.83 & 6.33 & 1.38 \\
White Peruvians & 3.51 & 0.92 & 6.41 & 1.61 \\
Mestizo Peruvians & 2.98 & 0.95 & 5.63 & 1.70 \\
Andean Peruvians & 2.21 & 0.89 & 5.54 & 1.81 \\
African Peruvians & 1.97 & 0.92 & 5.28 & 1.81 \\
Amazonian Peruvians & 1.92 & 0.89 & 5.41 & 1.79 \\
Asian Peruvians & 1.82 & 0.99 & 6.12 & 1.73 \\
\hline
\end{tabular}

Note: $M=$ mean; $S D=$ standard deviation

On the other hand, there were significant statistical differences in the participants' valuation of social groups $\left(\chi^{2}(5)=52.92, p<.001\right)$, also without considering Peruvians in general. The participants significantly valued Asian Peruvians more than African Peruvians $(p<.001, r=.47)$ and Amazonian Peruvians ( $p<.001, r=.37)$. Similarly, they valued White Peruvians more than the two aforementioned groups (African Peruvians $p<.001, r=.48$; Amazonian Peruvians $p<.001, r=.38$ ).

A correlation analysis between group identification and individual valuation of groups (Table 3) showed that the participants who identified themselves more with White Peruvians also valued this group significantly more ( $r h o=.49, p<.01$ ). The same correspondence was observed in the case of Andeans $(r h o=.35, p<.01)$, Amazonians ( $r h o=.33, p<$ $.01)$ and Mestizos (rho $=.31, p<.01$ ) but with less magnitude. Indeed, the association between social identification and valuation of White Peruvians is even greater than the association of the same variables in the case of a broader category as Peruvians in general ( $r h o=.46, p<.01)$. In addition, the more the participants valued White Peruvians, the less they identified themselves with Mestizos ( $r h o=-.35, p<$ .01 ), African Peruvians (rho $=-.21, p<.01$ ) and Andean Peruvians ( $r h o=-.21, p<.05$ ).

Table 3

Correlation between group identification and individual valuation of groups

\begin{tabular}{|c|c|c|c|c|c|c|c|}
\hline \multirow[b]{2}{*}{ Group Identification } & \multicolumn{7}{|c|}{ Individual Valuation of Groups } \\
\hline & Whites & Mestizos & Andeans & $\begin{array}{c}\text { African } \\
\text { Peruvians }\end{array}$ & Amazonians & Asians & $\begin{array}{l}\text { Peruvians in } \\
\text { general }\end{array}$ \\
\hline Whites & $.49 * *$ & -.09 & -.11 & -.13 & -.22 & .07 & .04 \\
\hline Mestizos & $-.35 * *$ & $.31 * *$ & $.29 * *$ & .17 & $.24 *$ & -.07 & .00 \\
\hline Andeans & $-.21 *$ & $.28 * *$ & $.35 * *$ & $.25 *$ & $.33^{* *}$ & .07 & $-21 *$ \\
\hline African Peruvians & $-.21 * *$ & .12 & .13 & .20 & .18 & .07 & -.02 \\
\hline Amazonians & -.16 & $.21^{*}$ & $.24 * *$ & $.22 *$ & $.33^{* *}$ & .16 & .12 \\
\hline Asians & -.14 & .13 & .05 & .07 & .05 & .16 & -.11 \\
\hline Peruvians in general & .12 & $.22 *$ & $.28 *$ & .17 & $.22 *$ & -.03 & $.46 * *$ \\
\hline
\end{tabular}

Note: $* * p<.01, * p<.05$. 
A within-subjects t-test was performed (Table 4) in order to compare participant's individual vs. perceived valuation of groups. As can be seen, the participants considered that other Peruvians value African, Andean and Amazonian Peruvians less than they do. Similarly, but with a lower effect size, the participants perceived that others value Asian Peruvians and Peruvians in general less than they do. On the other hand, there were not significant differences between individual and perceived valuation in the case of White and Mestizo Peruvians.
In addition, Friedman's ANOVA showed that there are significant differences in the perceived valuation of groups by the participants $\left(\chi^{2}(5)=176.09, p<\right.$ $.001)$. The results indicate that the participants consider that White Peruvians are the most valued group according to other Peruvians $(M=6.69, S D=1.90)$; more than African Peruvians $(p<.010, r=.90)$, Andeans $(p<.001, r=.86)$, Amazonians $(p<.001$, $r=.84)$, Mestizos $(p<.001, r=.37)$ and Asian Peruvians $(p<.001, r=.36)$.

Table 4

Mean differences of individual and perceived valuation of groups

\begin{tabular}{lccccc}
\hline \multicolumn{1}{c}{ Groups } & $\begin{array}{c}\text { Individual valuation } \\
M(S D)\end{array}$ & $\begin{array}{c}\text { Perceived valuation } \\
M(S D)\end{array}$ & $d f$ & $t$ & Cohen's $d$ \\
\hline White Peruvians & $6.41(1.61)$ & $6.69(1.90)$ & 89 & -1.17 & -.16 \\
Asian Peruvians & $6.12(1.73)$ & $5.29(1.82)$ & 89 & $5.35^{* *}$ & .47 \\
Mestizo Peruvians & $5.63(1.70)$ & $5.27(1.79)$ & 89 & 1.64 & .20 \\
Andean Peruvians & $5.54(1.86)$ & $4.07(1.71)$ & 89 & $5.96^{* *}$ & .82 \\
African Peruvians & $5.28(1.81)$ & $3.73(1.75)$ & 89 & $7.47^{* *}$ & .87 \\
Amazonian Peruvians & $5.41(1.79)$ & $4.41(1.65)$ & 89 & $6.24^{* *}$ & .58 \\
Peruvians in General & $6.33(1.38)$ & $5.82(1.54)$ & 89 & $3.39^{* *}$ & .35 \\
\hline
\end{tabular}

Note: $* * p<.01$.

\section{Part two: qualitative results}

The second part of the study provided new insights on the reasons why each of the social groups was associated with certain stereotypical attributes and had a certain valuation in the first part of the study. In some cases, the interviewed participants added other attributes that, in their opinion, characterize each of the social groups.

Regarding White Peruvians, most participants indicated that they are perceived as highly competent and as the most powerful group in the Peruvian society due to their economic leadership. Furthermore, this social group was associated with characteristics such as development and success.
I see them (White Peruvians) developed, because I think they're the group that leads the Peruvian economy. The owners of the big businesses are [...] from this group. (Male, 19 years old)

However, White Peruvians were also associated with attributes like individualism, corruption and discrimination. This last characteristic was attributed more to White Peruvians with high socioeconomic status.

At a prejudice level, these are the things that apply to White Peruvians: that they are developed, successful, individualist, capitalist, thus also associated with bad things such as corruption and high class. (Male, 24 years old) 
On the other hand, Asian Peruvians were perceived as hardworking, competent and reliable in terms of their performance in business.

There is this stereotype of Chinese food and grocery Chinaman, which are strong ideas in Lima; there's an idea of Asians associated to work. (Male, 24 years old)

On the other hand, African Peruvians were perceived by the participants as owning skills in areas that belong to low social classes such as sports, music and cooking. They were also seen as strenuous workers with great physical resistance. However, they were not characterized by their technical skills and they were even perceived as individuals with lower intelligence and less chances of pursuing educational studies.

... they may not have great academic degrees, but [...] they are skilled with their hands for... it's mean what I'm going to say, ok? But they are skilled at cooking, playing volleyball or music. (Female, 22 years old)

The most important characteristic associated to African Peruvians was joy, which was attributed to this group's musical, dancing and sporting skills. They were also distinguished as part of the middle class, mainly because they live in the coast and have adopted a modern coastal culture.

... the black man, the black woman who enjoys dancing, who dances very well. Who has the intrinsic joy that is usually expressed by dancing? (Male, 19 years old)

... middle class because African Peruvians live on the coast, where one can find more cities and development. (Male, 22 years old)

Amazonians were perceived as supportive, which comes from the idea that they live in communities and, therefore, are trustworthy, joyful and seek to help others.
I think they have the stereotype of being supportive, joyful, of being the sort of people that want to help you with everything. (Female, 24 years old)

In addition, the participants recognized that the Amazon region is characterized by a higher degree of poverty and, therefore, is more backward. However, most participants did not relate backwardness and failure as intrinsic characteristics of Amazonian people, since these attributes are caused by contextual factors such as the absence of government help in the region and its geographical hardships.

The backward and unsuccessful attributes may be because development has not arrived there so much; not so much because of their own characteristics. (Female, 24 years old)

Regarding representations of Amazonians, the participants claimed lack of knowledge of this group because they do not have direct contact with its members. The participants recognized that they usually base their opinions on what the mass media shows about this group.

...the reinforcement I get from the media is pretty negative, then, I would have to place them at the lowest rank. (Male, 22 years old)

The participants indicated that the Andean region of Peru is characterized by its poverty, which explains why its population is described as belonging to a low socioeconomic status. Therefore, like Amazonian Peruvians, Andeans were portrayed as backward and conformist; however, this is not seen as an intrinsic characteristic but rather as the result of the lack of opportunities.

...they are seen as conformists because they don't have the same resources as them (other Limeños), but if they were given the same opportunities and the same resources, I think that they are capable of doing anything. (Female, 22 years old) 
Despite the above mentioned facts, the participants see Andean-Peruvians as resentful because they blame others (the State, NGOs and wealthy economic groups) for their problems, and do not solve their situation by their own effort. They were also perceived as envious and distrustful individuals. However, Andean people who live in the Andean region were differentiated from those who migrated to the capital and adapted to the coastal culture: their migration to Lima is perceived as an act of bravery, since it implies the search for personal development. Because of this, migrant Andean people were perceived in a more positive way than the ones that stayed in their region.

They are resentful because they are always trying to blame the government, NGOs for their suffering... they don't solve them by themselves. (Female, 22 years old)

...in Lima things have been changing and the «cholo» goes from being perceived as backward [...] to, finally, being seen as brave. (Male, 24 years old)

Concerning the representation of Mestizos, the participants showed difficulties when trying to describe this group. They perceived them as the result of a mixture of races, being the group associated to most Peruvians. There is ambivalence regarding the way in which Mestizo Peruvians are conceptualized: on the one hand, they are highly valued and, on the other, they are seen as unreliable.

I believe that mestizos are highly valued, because they are what's normal, they see it as something normal, they don't see it as neither bad nor good. (Male, 19 years old)

...they are unreliable because they don't inspire much trust when doing things. Let's say, economic type of things, serious things, if they earn five soles they try to earn the sixth or the seventh using corrupt practices. (Male, 21 years old)
As for the representation of the participants of the broad category of Peruvians, they were perceived as hardworking people and creative in a practical sense; in spite of lacking technical skills and general competence, they use their resourcefulness and creativity to go ahead.

Competent, I don't know, because it includes technical capacity, and not many people have the capacity to solve a mathematical problem. I mean, I wouldn't use the word competent; I'd use creative, witty. (Female, 19 years old)

In addition, Peruvians were described as joyful, since, even in adverse situations, they keep a positive attitude. Although this joy is often interpreted as a sign of conformism, some participants revealed that this stereotype is changing, since they perceived Peruvians in a more positive manner, with more chances of improving their current situation.

... I think they are conformists and joyful, well... I see it like the fact that they live a happy life... (Female, 19 years old)

I don't (believe they are conformists). I believe it's something that has always been seen, like a trademark of Peruvians, but I believe that this is fading slowly, with all that we are improving. (Female, 24 years old)

\section{General Discussion}

The present study examined the stereotypical representations and prejudices towards different Peruvian social groups according to members of the high socioeconomic level in Lima. This was performed using a mixed-method design that contributed to converge the quantitative and qualitative results, in order to explore the complex dynamic of stereotypes and prejudices towards social groups in the Peruvian society. As such, the quantitative results allowed to identify the most representative attributes associated with each of the social groups, and the groups towards whom the participants hold the strongest identification 
and valuation. To complement these first results, the qualitative findings offered a broader description of each of the social groups and their relations, as well as new insights on the reasoning behind the stereotypes given to each of them.

As Fiske et al. (2002) report, stereotypical representations of social groups, as well as prejudice towards them, are typically ambivalent, and it is constituted around two general dimensions: competence and warmth. Although the attributes included in this research were not selected or classified according to these dimensions (Fiske et al., 2002), results indicated that the perception of most social groups was aligned with this theory. The White Peruvians group, for example, was perceived as a group with high competence (e.g., successful, competent), but with low warmth (e.g., individualist, corrupt). The attributes of low warmth reinforce the competence of the group, since individualism and corruption are seen in some sectors of the country as legitimate means to obtain and maintain power (Espinosa et al., 2007). In contrast to White Peruvians, African Peruvians showed a strong relationship with warmth attributes and a weak association with competence. Again, the abilities seen as characteristic of this group (those related with music, sports and cooking) seem to support their perception as a warm group.

Although there is a tendency among Peruvians to identify themselves as Mestizos (Latinobarómetro, 2011; Espinosa, 2011; Portocarrero, 1992), most participants in this research identified themselves with the White Peruvian group. This identification could be motivated by the desire to belong to the best valued category, which possesses attributes that are most appreciated both individually and collectively. In a similar vein, the results obtained by Pancorbo et al. (2011) with the low socioeconomic status sample indicated that the participants not only identified themselves the most with Andean and Amazonian Peruvians but also valued them greatly. This motivation can be explained by the role that social identity plays in the enhancement of self-esteem (cf. Tajfel \& Turner, 1986).

It is noteworthy the case of Asian Peruvians as they were not characterized by attributes associated with the warmth dimension but instead with attributes related to the competent dimension. Asian and African Peruvians were historically social groups placed under slavery conditions in Peru (Gómez, 2005). Nevertheless, Asian Peruvians have managed to overcome this stereotype and they are nowadays related to hard work, success and modernity. This is reinforced, partly, by the stereotype of the Asian foreigner, which is associated with hard work, technology and development.

The stereotype towards African Peruvians may be influenced by the participants' desire of not being perceived as discriminatory people. Since the common idea is that in Peru «all -White, Indian and Mestizodespise the Black» (Vargas Llosa \& Munné, 2004, p. 1106), perceiving this group in a negative manner could be socially reproached. Because of this, there is a tendency to compensate their low competence attributes with other characteristics associated with the warmth dimension: on the one hand, African Peruvians are perceived as technically and academically poorly competent; and, on the other, they are perceived with characteristics such as joyful, supportive and good dancers, attributes that define them as expressive and warm. This could be the manifestation of a benevolent prejudice, which, although it does not express antipathy, legitimates the inclusion of African Peruvians as part of a low-status group (Espinosa et al., 2007).

The relatively low valuation and inferior levels of competence attributed to Andeans seems to be motivated by the perception that they are a group marked by resentment and envy towards the highstatus groups. However, the participants show a better valuation for Andeans who migrate to Lima and insert themselves in the coastal urban system, making local customs and values their own. Migrants are better evaluated since it is perceived that they are seeking 
for improvement in a region which is considered to be the country's power and development center. Additionally, this contextual influence on prejudice is present in the valuation of other social groups such as African Peruvians. More research is required in order to clarify the relationship between context and perception of social groups.

Overall, Amazonians tend to be portrayed as a noncompetent group, since they are seen as an isolated group with no direct connection with the modern coastal area of Peru. However, there is a partially positive perception of Amazonians, characterized by attributes associated with the warmth dimension, such as joyful and supportive. Additionally, the geographical and cultural distance from the capital city results in a poorer knowledge of their traditions and lifestyle, making the media and advertisement the most accessible sources of information to construct knowledge of this particular group. It is important to highlight the role that the media plays in the characterization and stereotyping of Amazonians and other social groups in Peru. In some cases, the participants knew little or nothing about the groups, and they consciously turned to descriptions they learned from the media when characterizing them.

The Mestizo category is perceived as the group that better describes the mixture of races that characterizes Peruvians. Because of this, it is seen as a key factor for inclusion and integration, since it could represent a common ground for all Peruvians; for this reason, it is conceptualized in a very similar way as Peruvians in general. Both groups condense the characteristics that are valued in other Peruvian groups (hardworking, patriotic and competent) and many which are considered negative (cunning and conformist).

It is important to highlight the importance of social class when representing groups in Peru, such as the relationship between Indigenous people and poverty (Portocarrero, 1992). This kind of subjective representations correlates with Peruvian social reality: for instance, Andean, Amazonian and African Peruvians were cataloged as low class individuals in this study and, according to national statistics, $46 \%$ of the Indigenous and African Peruvian population live in poverty in Peru (Instituto Nacional de Estadística e Informática [National Institute of Statistics and Informatics], INEI, 2015). However, the common associations between social groups and social classes may serve theoretically to another purpose. Being cataloged as a person who discriminates based on race is perceived as a strong interpersonal threat (Fiske \& Taylor, 2007), and is related to feelings of shame and guilt (Bruce, 2007). Social class is a category on which the individual can build prejudices with fewer restrictions and evade social sanctions. In this way, biological discrimination is concealed with prejudices based on social classes, and this is covered, in turn, with arguments grounded on education and cultural differences (Cosamalón, 1993; Twanama, 1992) which receive less social restraint. This expression of discrimination can also be corroborated by different responses on individual and perceived valuation of groups. In this case, the participants assigned similar scores to every social group when asked for their own opinion, but gave different ratings when they addressed others' points of view. When compared those evaluations with the descriptions they gave to the social groups, it would seem as if they tried to mask their own opinion in order to avoid being perceived as discriminators.

As mentioned earlier, previous analyses evidence that, in Peru, social groups are perceived in an ambivalent way, which is consistent with causes of modern prejudice and ambivalence, fostered by the need to appear «politically correct». This configuration of prejudice and stereotyping goes beyond the Peruvian case, since there are and have been common patterns in other Latin American countries. Ambivalent representations are common among social groups, where attributes associated with competence are ascribed to high-status groups, and those related to warmth are attributed to low-status groups (Fiske et al., 2002). Furthermore, in other countries of the 
region, high-status groups generally include White and Mestizo populations, while low-status groups consist of Indigenous or African-descent populations (Camino, da Silva, Machado, \& Pereira, 2001; Espinosa \& Cueto, 2014; Ishibashi, 2003; Traverso-Yépez, 2005; Van Dijk, 2007).

Latin American countries share a bond so strong that it implies the manner in which they understand themselves, perceive the groups in their societies and value these groups. Therefore, due to the prevalence of negative and fragile social identities, as well as a disadvantageous comparison with higher-status societies such as Europeans or other White cultures, it has been hypothesized that Latin American citizens display a phenomena called «altercentrism» (Montero, 1991). In particular, this phenomenon manifests as the «whitening» of natives and Mestizos, which can serve as an instrument for social recognition and mobility (see Tajfel \& Turner, 1979).

Moreover, the participants' perceptions of social groups in Peru seem to follow a compensation pattern, such that targets higher in one of the two dimensions tend to be seen as low in the other one. Indeed, the most valued group (i.e., White Peruvians) was pictured as competent (e.g., successful, high class, competent) but not sociable (e.g., individualist, corrupt, unpatriotic). On the other hand, low-status groups (i.e., African, Amazonian and Andean Peruvians) were described in an opposite way: highly warmth (e.g., joyful, supportive, patriotic) but lacking of competence (e.g., incompetent, unsuccessful, low class). As Cambon et al. (2015) pointed out, this compensation pattern seems to be bolstered by contexts with asymmetrical relationship in groups combined with low levels of violent intergroup conflict (cf. Cueto, 2017).

Furthermore, studies have shown that compensation can be moderated by group membership, such that group members exhibit outgroup favoritism in their less favored dimension only to the extent that they can achieve positive differentiation in their in-group-favored dimension
(Cambon et al., 2015). Because most participants in the study generally identify themselves with White Peruvians, which is the dominant group, they tend to favor their in-group in the competence dimension while also crediting the lower-status groups with warmth but not competence. This specific pattern corresponds to what has been called the «noblesse oblige effect» and is prone to take place when nondiscriminant pressures are at stake, as in the case of the Peruvian society. In this regard, Yzerbyt and Cambon (submitted), argued that this tendency may be accounted by the differential objectivity of the two dimensions. Specifically, the competence dimension would be perceived as more objective than the warmth dimension. As a consequence, low-statusgroup members would be «forced» to recognize the competence of high-status groups, whereas highstatus-group members would have the possibility to achieve positive distinctiveness in both dimensions.

The present study is not exempt of limitations. The samples of the two parts of the study were collected by convenience and were reduced in number, which was partly due to the difficulties in selecting participants from the high socioeconomic level. Also, in the quantitative part, the sample mainly consisted of young adults (mostly between 10 and 30 years old), while the sample of the qualitative part was unbalanced in terms of gender distribution as there were more males participating than females. Future studies should increase the number of participants and improve the data collection process from specific socioeconomic groups as the one proposed in this study. In addition, future studies should include other measures, or redefine the existing ones, to explore stereotypes by following specific theoretical perspectives as the stereotype content model that proved to be useful to understand the results of the present study. In this regard, the nature of the measure used in this study prevented from performing multivariate analyses, which may have shed light on the structure of stereotype content. Finally, it is recommended the use of additional measures to assess the implicit expression of prejudices. 


\section{Conflict of interests}

The authors have declared that there are no competing interests.

\section{Ethical responsibility}

In both parts of the study, the participants were asked to read and sign the informed consent. The principles of voluntariness, anonymity and confidentiality in participation were taken into account. All the participants have been duly informed of their rights, as well as the fact that participating (or not doing so) does not imply any type of risk or harmful situation for them. The confidentiality of the data was maintained at all times. The questionnaires were applied in physical. Likewise, there are no elements to identify the participants. The interviews were recorded with a code that does not allow the personal identification of the interviewee. There is no data to identify individual participants, the data has been analyzed collectively and only for strictly academic purposes.

\section{Contribution of authorship}

GPPV, MS, INF, AMPA, AE: All authors were involved in the entire research process.

\section{References}

Abrams, D., \& Hogg, M. A. (1990). An introduction to the social identity approach. In D. Abrams \& M. A. Hogg (Eds.), Social Identity Theory. Constructive and critical advances (pp. 1-10). New York: Harvester Wheatsheaf.

Allport, G. (1954). The nature of prejudice. Boston, MA: Addison-Wesley.

APEIM (2010). Fórmula APEIM - NSE LIMA 2010. Retrieved from http://www.apeim.com.pe/niveles.html

APEIM (2014). Fórmula APEIM - NSE LIMA 2014. Retrieved from https://www.coursehero.com/file/ 43463685/APEIM-NSE-2018pdf/

Avilés, M. (2016). De dónde venimos los cholos. Lima: Seix Barral.
Bodenhausen, G. V., Mussweiler, T., Gabriel, S., \& Moreno, K. N. (2001). Affective Influences on Stereotyping and Intergroup Relations. In J. P. Forgas (Ed.), Handbook of Affect and Social Cognition. Manhaw, NJ: Lawrence Erlbaum Associates.

Bruce, J. (2007). Nos habíamos choleado tanto. Psicoanálisis y racismo. Lima: Fondo Editorial de la Universidad de San Martín de Porres.

Camino, L., da Silva, P., Machado, A., \& Pereira, C. (2001). A face oculta do racismo no Brasil: Uma Análise Psicossociológica. Revista de Psicologia Política, 1, 13-36.

Cambon, L., \& Yzerbyt, V. Y. (2018). Two routes toward compensation: An investigation into the mechanisms of compensation for high-and low-status groups. Journal of Experimental Social Psychology, 77, 24-35.

Cambon, L., Yzerbyt, V., \& Yakimova, S. (2015). Compensation intergroup relations: An investigation of its structural and strategic foundations. British Journal of Social Psychology, 54, 140-158.

Cosamalón, A. L. (1993). El lado oculto de lo cholo. Allpanchis, 4, 211-226.

Creswell, J. W. (2003). Research Design: Qualitative, Quantitative, and Mixed Methods Approaches. $2^{\text {nd }}$ edn. California: Sage Publications.

Cueto, R. M. (2017). Estudios sobre relaciones intergrupales, identidades colectivas e ideología política en dos regiones del Perú (unpublished doctoral dissertation). Pontificia Universidad Católica del Perú, Lima, Perú. Retrieved from http:// hdl.handle.net/20.500.12404/9201

Cuddy, A., Fiske, S., \& Glick, P. (2007). Warmth and competence as universal dimensions of social perception: The stereotype content model and the BIAS map. Advances in Experimental Social Psychology, 40, 61-149.

Dovidio, J. F., Pearson, A. R., \& Penner, L. A. (2018). Aversive Racism, Implicit Bias, and Microaggressions. Microaggression Theory, 16-31. doi:10.1002/ 9781119466642.ch2

Durante, F., Tablante, C. B., \& Fiske, S. T. (2017). Poor but warm, rich but cold (and competent): Social 
classes in the stereotype content model. Journal of Social Issues, 73(1), 138-157.

Espinosa, A. (2003). Identidad social e identidad nacional en una muestra de triciclistas en Juliaca (Unpublished undergraduate degree thesis). Pontificia Universidad Católica del Perú, Lima, Perú.

Espinosa, A. (2011). Estudios sobre identidad nacional en el Perú y sus correlatos psicológicos, sociales y culturales (Unpublished doctoral dissertation). Universidad del País Vasco, San Sebastián, Spain.

Espinosa, A., Calderón-Prada, A., Burga, G., \& Güímac, J. (2007). Estereotipos, prejuicios y exclusión social en un país multiétnico: el caso peruano. Revista de Psicología, 15(2), 296-331.

Espinosa, A., \& Cueto, R. M. (2014). Estereotipos raciales, racismo y discriminación en América Latina. In E. Zubieta, J. Valencia, \& G. Delfino (Eds). Psicología Social y Política: procesos teóricos y estudios aplicados (pp. 431-442). Buenos Aires: EUDEBA.

Fein, S., \& Spencer, S. J. (1997). Prejudice as self-image maintenance: Affirming the self through derogating others. Journal of Personality and Social Psychology, 73, 31-44.

Fiske, S. T. (1998). Stereotyping, prejudice, and discrimination. In D. Gilbert, S. T. Fiske, \& G. Lindzey (Eds.), Handbook of social psychology (pp. 357411). New York: McGraw-Hill.

Fiske, S. T. (2000). Stereotyping, prejudice, and discrimination at the seam between the centuries: evolution, culture, mind, and brain. European Journal of Social Psychology, 30, 188-211.

Fiske, S. T. (2015). Intergroup biases: A focus on stereotype content. Current opinion in behavioral sciences, 3, 45-50.

Fiske, S. T., Cuddy, A., Glick, P., \& Xu, J. (2002). A model of (often mixed) stereotype content: competence and warmth respectively follow from perceived status and competition. Journal of Personality and Social Psychology, 82, 878-902.

Fiske, S. T., \& Taylor, S. (2007). Social Cognition: From Brains to Culture. New York: McGraw- Hill.
Gaertner, S. L., \& Dovidio, J. F. (1986). The aversive form of racism. In J. F. Dovidio \& S. L. Gaertner (Eds.), Prejudice, discrimination and racism (pp. 6190). San Diego: Academic Press.

Genna, K., \& Espinosa, A. (2012). Identidad, Etnicidad y Bienestar Social en un contexto socialmente excluyente. Psicología \& Sociedade, 24(1), 84-93.

Gómez, A. (2005). Los inmigrantes chinos en el Perú. Retrieved from http://historiaperuana.blogspot.com/ 2005/12/los-inmigrantes-chinos-en-el-per.html

Hamilton, D. L. (1981). Cognitive Processes in Stereotyping and Intergroup Behavior. Hillsdale, NJ: Lawrence Erlbaum Associates.

Hernández Sampieri, R., Fernández Collado, C., \& Baptista Lucio, P. (2010). Metodología de la investigación. México DF: McGraw-Hill

Heyvaert, M., Maes, B., \& Onghena, P. (2011). Mixed methods research synthesis: Definition, framework, and potential. Quality \& Quantity, 47(2), 659-676.

Hyde-Clarke, N. (2008). Beyond stereotypes: representations of a foreign culture in film students' productions. Literator, 29(2), 149-167.

INEI. (2015). Perú: Perfil de la pobreza por dominios geográficos 2004-2014. Retrieved from https:// www.inei.gob.pe/media/MenuRecursivo/ publicaciones_digitales/Est/Lib1306/libro.pdf

IOP-PUCP (abril, 2018). Boletín $N^{\circ} 151$ Estado de la Opinión Pública: Experiencias de discriminación étnico-cultural en el Perú. Retrieved from http:// repositorio.pucp.edu.pe/index/handle/123456789/ 123821

Ishibashi, J. (2003). Hacia una apertura del debate sobre el racismo en Venezuela: exclusión e inclusión estereotipada de personas negras en los medios de comunicación. In D. Mato (Ed.), Políticas de identidades y diferencias sociales en tiempos de globalización (pp. 33-61). Caracas: FACES-UCV.

Jost, J. T., \& Banaji, M. R. (1994). The role of stereotyping in system-justification and the production of false consciousness. British Journal of Social Psychology, 33, 1-27 
Kervyn, N., Yzerbyt, V., \& Judd, C. (2010). Compensation between warmth and competence: Antecedents and consequences of a negative relation between the two fundamental dimensions of social perception. European Review of Social Psychology, 21, 155187. doi: 10.1080/13546805.2010.517997

Latinobarómetro. (2011). Informe 2011. Retrieved from http://www.slideshare.net/FUSADESORG/informelatinobarometro-2011

León, R. (1998). Humillados y ofendidos: un estudio acerca del desprecio y discriminación en el Perú. Revista de Psicología, 16(1), 45-81.

Montero, M. (1991). Una orientación para la Psicología Política en América Latina. Psicología Política, 3, 27-43.

Pancorbo, G., Espinosa, A., \& Cueto, R. M. (2011). Representaciones estereotípicas y expresión del prejuicio en el Perú: la mirada desde la pobreza. Revista de Psicología, 29(2), 311-342.

Portocarrero, G. (2006, setiembre). Hacia una comprensión del racismo. Página de Gonzalo Portocarrero. Retrieved from http:// gonzaloportocarrero.blogsome.com/2006/09/27/ hacia-una-comprension-del-racismo/

Portocarrero, G. (1992). Del racismo al mestizaje: una apuesta por la integración. In G. Portocarrero (Ed.), Los quinientos años: un espacio para la reflexión (pp. 31-41). Lima: Allpamérica.

Reding, S. (2007). Diversidad y Racismo en América Latina. Latinoamérica. Revista de Estudios Latinoamericanos, 44, 157-179.

Schaller, M., \& Crandall, C. S. (2004). The psychological foundations of culture. Mahwah, NJ: Lawrence Erlbaum Associates.

Song Hing, L. S., Bodocel, D. R., Zanna, M. P., Garcia, D. M., Gee, S. S., \& Orazietti, K. (2011). The Merit of Meritocracy. Journal of Personality and Social Psychology, 101(3), 433-450. doi: 10.1037/ a0024618

Stangor, C. (2009). The study of stereotyping, prejudice and discrimination within social psychology: A quick history of theory and research In T. D. Nelson (Ed.), Handbook of Prejudice, Stereotyping and
Discrimination (pp. 1-22). New York: Psychology Press.

Tajfel, H. (1969). Cognitive aspects of prejudice. Journal of Social Issues, 25, 79-97.

Tajfel, H., \& Forgas, J. P. (1981). Social categorization: Cognition, values, and groups. In J. P. Forgas (Ed.), Social Cognition: Perspectives on Everyday understanding (pp. 113-140). London: Academic Press.

Tajfel, H., \& Turner, J. C. (1979). An integrative theory of intergroup conflict. In W. G. Austin \& S. Worchel (Eds.), The social psychology of intergroup relations (pp. 33-48). Monterey, CA: Brooks/Cole.

Tajfel, H., \& Turner, J. C. (1986). The Social Identity Theory of Intergroup Behavior. In S. Worchel \& G. Austin (Eds.), Psychology of intergroup relations (Rev.Vol. 2), (pp. 7- 24), Chicago: Nelson-Hall.

Traverso-Yépez, M. (2005). Discursos Racistas: Institucionalización del Racismo a través de las prácticas lingüísticas. Revista Interamericana de Psicología, 39, 61-70.

Turner, J. C., Brown, R. J., \& Tajfel, H. (1979). Social comparison and group interest in ingroup favouritism. European Journal of Social Psychology, 9, 187-204.

Twanama, W. (1992). Cholear en Lima. Márgenes, 9, 207-240.

Van der Toorn, J., Feinberg, M., Jost, J. T., Kay, A. C., Tyler, T. R., Willer, R., \& Wilmuth, C. (2015). A sense of powerlessness fosters system justification: Implications for the legitimation of authority, hierarchy, and government. Political Psychology, 36(1), 93-110.

Van Dijk, T. A. (2007). Racismo y discurso en América Latina: una introducción. In T. A. Van Dijk (Ed.). Racismo y discurso en América Latina (pp. 21-34). Barcelona: Gedisa.

Vargas Llosa, M. \& Munné, A. (2004). Obras Completas VI: Ensayos literarios I. Barcelona: Galaxia Gutenberg.

Volpato, C., Andrighetto, L., \& Baldissarri, C. (2017). Perceptions of low status workers and the maintenance of the social class status quo. Journal of Social Issues, 73(1), 192-210. 
Yzerbyt, V. (2016). Intergroup stereotyping. Current Opinion in Psychology, 11, 90-95.

Yzerbyt, V. (2018). The dimensional compensation model: Reality and strategic constraints on warmth and competence in intergroup perceptions. In A. Abele \& B. Wojciszke (Eds.), Agency and Communion in Social Psychology (pp. 126-141). London, UK: Routledge.

Yzerbyt, V. Y., \& Cambon, L. (2017). The dynamics of compensation: When ingroup favoritism paves the way for outgroup praise. Personality and Social
Psychology Bulletin, 43, 587-600. doi:10.1177/ 0146167216689066

Yzerbyt, V., Provost, V., \& Corneille, O. (2005). Not Competent but Warm... Really? Compensatory Stereotypes in the French-speaking World. Group Processes \& Intergroup Relations, 8(3), 291-308.

Zárate, M. (2009). Racism in the 21st Century. In T. Nelson (Ed.) Handbook of Prejudice, Stereotyping and Discrimination (pp. 387-406). New York: Psychology Press.

\section{Gina Pamela Pancorbo Valdivia}

Universidad de Gante (Ghent University, Bélgica)

Bachiller en Letras y Ciencias Humanas con Mención en Psicología (PUCP), Licenciada en Psicología con Mención en Psicología Social (PUCP). Magíster en Psicologia Social, do Trabalho e das Organizações- Universidad de Brasília. Ha sido Docente TPA del Departamento Académico de Psicología (PUCP). Candidata a doctora en la Facultad de Psicología y Educación de la Universidad de Gante (Ghent University). ORCID: 0000-0002-8970-114X

gpancorbo@gmail.com

\section{Mathias Schmitz}

Université catholique de Louvain (UCLouvain, Bélgica); Pontificia Universidad Católica del Perú (PUCP)

Bachiller en Letras y Ciencias Humanas con Mención en Psicología (PUCP), Licenciada en Psicología con Mención en Psicología Social (PUCP). Magíster en Ciencias Psicológicas (UCLouvain). Ha sido Docente TPA del Departamento Académico de Psicología (PUCP). Candidato a doctor en la Facultad de Psicologia de la Université catholique de Louvain (UCLouvain).

ORCID: 0000-0001-9272-5874

Autor corresponsal: mathias.schmitz@pucp.pe

Ian Nightingale Ferrer

Pontificia Universidad Católica del Perú, Perú

Psicólogo social de la Pontificia Universidad Católica del Perú. Profesor contratado de esa misma universidad y Coordinador de Creación de Valor Compartido para Nestlé Perú y Bolivia, especializado en sostenibilidad empresarial y responsabilidad social corporativa.

nightingaleian88@gmail.com

\section{Andrés Manuel Palacios Agurto}

Pontificia Universidad Católica del Perú, Perú

Psicólogo social de la Pontificia Universidad Católica del Perú. Senior Strategic Planner en Tribal 121, encargado de la investigación y generación de estrategias para campañas publicitarias.

andpal21@gmail.com

\section{Agustín Espinosa}

Pontificia Universidad Católica del Perú, Perú

Bachiller en Letras y Ciencias Humanas con Mención en Psicología (PUCP), Licenciado en Psicología con Mención en Psicología Social (PUCP). Doctor en Psicología Social por la Universidad del País Vasco, España. Profesor principal del Departamento Académico de Psicología (PUCP)

ORCID: 0000-0002-2275-5792

agustin.espinosa@pucp.pe 